\title{
Using a Direct Instruction Flashcard System with Two Students with Learning Disabilities
}

\author{
Patti Glover $^{1}$, Thomas McLaughlin ${ }^{1}$, \\ K. Mark Derby ${ }^{1}$, Jan Gower ${ }^{2}$
}

${ }^{1}$ Department of Special Education, Gonzaga University, Spokane, WA

${ }^{2}$ Special Education Teacher, Spokane Public Schools, Spokane, WA

USA

Correspondence: Thomas McLaughlin. Department of Special Education, Gonzaga University, Spokane, WA 99258-0025. USA. E-mail: tim.mclaughlin6@,comcast.net

(C) Education \& Psychology I+D+i and Editorial EOS (Spain) 


\begin{abstract}
Introduction. The use of Direct Instruction (DI) flashcards has been suggested as an effective classroom intervention procedure. The present case report examined the use of DI flashcards with two adolescents with learning disabilities.

Objectives. The purpose of this research was to increase the correct rate and decrease the error rate for see/write digits in multiplication using DI Flashcards and a back three strategy for errors. Another objective was to provide an expansion and replication of our previous work with DI flashcards.

Method. Our participants were two elementary students learning disabilities. After baseline, a Direct Instruction flashcard procedure was implemented. The study was conducted in a resource room that served intermediate aged elementary students. The school was located in a high poverty area of a large urban school district. The effects of our intervention were evaluated in a multiple baseline design across students.
\end{abstract}

Results. Each participant improved their mastery of math facts. These changes were immediate and large for the first two sets. Some generalization to the problems in last set of problems was found for both participants.

Discussion. The flash card procedure was inexpensive and easily implemented in a resource room setting. Recommendations for employing DI flashcards by teachers are provided.

Key Words: DI Flashcards, Math Facts, Learning Dsabilities, Action Research, Multiple Baseline Research Design.

Received: 12/09/09 Initial Acceptance: 12/10/09 Definitive Acceptance: 04/20/10 


\section{Uso de un sistema de tarjetas de instrucción directa con dos alumnos con dificultades de aprendizaje}

\section{Resumen}

Introducción. La utilización de la Intrucción directa (ID) con tartjetas ha sido señalada como un procedimiento intervención de aula efectivo. El presente trabajo examina el uso de un sistema de tarjetas de instrucción directa con dos adolecentes con dificultades de aprendizaje.

Objetivos. El propósito de esta investigación fue incrementar la tasa de respuestas correctas y disminuir la tasa de error en la visión/escritura de dígitos en multiplicaciones utilizando un sistema de tarjetas de instrucción directa con una estrategia de repetición de tres tarjetas tras los errores. Otro objetivo fue favorecer la extensión y replicación de trabajos previos realizados con la metodología de instrucción directa.

Método. Los participantes fueron dos estudiantes de enseñanza elemental con dificultades de aprendizaje. Tras la establecer la línea base, se implementó el sistema de tarjetas a través de instrucción directa. El estudio fue realizado en un aula del centro. La escuela estaba situada en un área de nivel alto de pobreza de una zona urbana. Los efectos de la intervención fueron evaluados mediante un diseño de múltiples líneas basales para cada estudiante.

Resultados: Ambos participantes mejoraron su capacidad en relación con las tareas matemáticas. Estos cambios fueron inmediatos y se extendieron durante los primeros dos pasos. Algunos problemas de generalización en los últimos pasos fueron observados para ambos participantes.

Discusión. El sistema de tarjetas fue poco costoso y fácil de implementar. Se proporcionan algunas recomendaciones para la utilización de este sistema.

Palabras Clave: Intrucción Directa, sistema de tarjetas, matemáticas, dificultades de aprendizaje, investigación-acción, diseño de línea base múltiple.

Recibido: 09/12/09 Aceptación Inicial: 10/12/09 Aceptación Definitiva: 20/04/10 


\section{Introduction}

Basic multiplication and division facts are imperative for the success of students in primary, intermediate, middle and high school classes and even higher education (Johnson \& Layng 1994; Stein, Kinder, Silbert, \& Carnine, 2006). Despite this requirement, thousands of students have struggled to learn and retain the required math benchmarks required for their grade level. This continuing issue has caused great concern for parents, teachers and policy makers (Stein et al., 2006). These academic outcomes in conjunction with other educational issues led to The No Child Left Behind Act of 2001. This act (United States Congress, 2002) has had a residual effect on teachers and students throughout the United States. Specifically, both are being held more accountable for their overall academic performance (Altwerger, Arya, Jordan, \& Martens 2004). This law encourages, and in some cases requires, teachers to change their instructional approach. Changing instructional approaches may be difficult and time consuming, especially with veteran teachers. Despite these challenges, all teachers need to take the initiative to create a more effective learning environment for each and every student.

In today's society, almost 90 percent of all new jobs require at least a high school level of math proficiency (Livingstone, 1998). Consequently, teachers need to search for a new and better way to educate students. Thus, mathematical instruction plays an important role within our society, and the evaluation of mathematical achievement in the United States and other developed countries needs to be addressed (Rivera-Batiz, 1992). The achievement scores specifically related to mathematics in the United States has been grim; with wide achievement gaps and low proficiency rates. Consequently it needs to be researched and urgently addressed. These wide achievement gaps have become a great concern for parents, teachers and administrators across our nation.

Several factors may explain the poor mathematical performance among U.S. students. Textbooks and educational materials are poorly designed, consequently they fail to develop or provide the critical steps necessary for developing a complete mathematical understanding of critical concepts (Stood \& Jitendra, 2007). Instructional models for teaching math need to emphasize clear and well-defined lesson plans. Thus they need to be designed around small group instruction. A recent meta-analysis found that direct instruction was the most effective 
procedure to teach students with disabilities basic math facts (Kroesbergen \& Van Luit, 2003).

Flashcards have been suggested as a easy way to teach students discrete skills such as sounds, letter names, important dates in history, etc (Heron, Heward, Cooke, \& Hill, 1983; Maheady \& Sainato, 1985; Olenick \& Pear, 1980; Van Houten \& Rolider, 1989; Young, Hecimovic, \& Salzberg, 1983). Flashcards have been employed to teach both young children and older students with a wide range of skills in math.

Many of the procedures associated with Direct Instruction such as: (a) model, lead, and test error correction: (b) systematic instruction; (c) systematic review; (d) teaching only the behaviors that are required in later learning of complex skills; (e) providing additional drill and practice, and (f) the use of systematic feedback have a very robust research base (Marchand-Martella, Slocum, \& Martella, 2004). One of the three methods suggested by Silbet, Carnine, and Stein (1981) to improve student performance with basic math facts has been is called a Direct Instruction flashcard system. The use of a flashcard strategy is unique; in that, it can be implemented in almost any setting and it teaches specific skills quickly (VanHouten \& Rolider, 1989). Direct instruction flashcard systems (Brasch, Williams, \& McLaughlin, 2008; Hayter, Scott, McLaughlin, \& Weber, 2007; Sante-Delli, McLaughlin, \& Weber, 2001; Silbert, Carmine, \& Stain, 1981) have received some attention in the literature. Sante Delli and colleagues (2001) reported that for two elementary students with mild mental retardation and ADHD increased their fluency for corrects and decreased their errors using flashcards. Brasch and collaborators (2008) found that the use of such procedures improved the accuracy and retention of math facts with two high school students enrolled in an alternative high school setting. Hayter and colleagues (2007) reported that two high school students in a self-contained classroom with mild mental retardation could improve the performance for basic math facts.

\section{The Present Study}

Since our prior DI flashcard research involved high school students with mental retardation (Hayter et al., 2007), behavior problem and ADHD (Brasch et al., 2008), or elementary students with moderate mental retardation in a self-contained classroom (Delli Sante et al., 
2001), the purpose of this investigation was to extend and replicate the use of flashcards to elementary students with learning disabilities in a less restrictive setting (resource room).

\section{Method}

\section{Participants}

Two elementary students with learning disabilities enrolled in a special education served as our participants. Both boys were diagnosed with a learning disability and one was also diagnosed with Attention Deficit Hyperactivity Disorder (ADHD). Justin was a 12-yearold boy that was below grade level in math. He was recommended for the project by his special education teacher because of his difficulty learning and retaining his basic facts in long division. Dustin was an 11-year-old boy that had difficulty learning his multiplication facts. The special education teacher felt that both boys would needed extra help in mathematics to reach their Individual Education Plan (IEP) goals in math. These goals were established by interdisciplinary team which included a general education teacher special education personnel, school district personnel (school psychologist, principal, and counselor)

\section{Instruments}

The materials used were 3 by 5 index cards with multiplication facts for Dustin and division facts for Justin. The multiplication facts were arranged vertically and the division facts were arranged horizontally. The multiplication facts were arranged with one number over another and a line drawn to represent the equal sign. The division facts were arranged with the division bracket. Both sets of flashcards were constructed for inclusion in the current investigation. In addition to the current academic intervention, contingent praise was provided that consisted of high fives and other compliments across all phases of the evaluation. Both boys were informed that they would be receiving a prize at the end of the study. This prize was a mechanical pencil with extra lead and erasers, and it was provided for the participants by the teachers who conducted the intervention. 


\section{Procedure}

The study was conducted in the resource room of an inner city elementary school in a lower socioeconomic area in the Pacific Northwest. The classroom had a diverse population of students (i. e. wide range of ages, grade levels and behavioral issues). Justin and Dustin both spent time between the resource room and a general education classroom. The resource classroom was staffed by a certified special education teacher, a student teacher from a local private university (McLaughlin, Williams, Williams, Derby, Peck, Bjordahl, \& Weber, 1999), typically one or two instructional aides in the resource room. The classroom utilized many Direct Instruction curricula (e.g. math, reading, spelling), which have been shown to be successful for students with learning disabilities (Marchand-Martella et al., 2004; Silbert et al., 2004). Most of the students were enrolled in the resource room because they had fallen behind on one or more academic areas (e.g. reading, math, written language) and required specialized instruction. Large tables and mobile chalkboards were used to create small group environment when working with students. The classroom was relatively quiet in the afternoon when the study was conducted. The classroom could be characterized as having a relaxed classroom atmosphere where students were allowed get up and walk around if they felt the need. The relationships between the students and staff were quite good. Thus the students were willing to participate in the instructional format required in the resource room.

\section{Dependent Variables}

For Justin, the dependent variable was his performance on three sets of division facts. For Dustin the dependent variable was his performance on three sets of multiplication facts. These data were gathered over 19 sessions for Dustin and 22 sessions for Justin.

Data were collected on separate sheets with all of the multiplication facts in one packet for Dustin and all of the division facts in one packet for Justin. There were three sets of facts for each boy; thus, each set of facts was labeled so data could be quickly and accurately gathered. Both participants were required to verbally state the entire problem and answer (i.e. "ten divided by two equals five/three times six equals eighteen") for each presented card to be awarded a correct response. The researchers modeled the desired behavior and the participants orally stated the entire problem and answer within two seconds. An error was defined as giving the wrong answer or by verbally delaying for more than two seconds. When 
an error was made a minus sign (-) would be recorded in the corresponding box on the data collection form. A correct response was defined as correctly stating the problem and answer within approximately two seconds. When a correct response occurred, a plus $(+)$ sign was recorded in the corresponding box on the data collection form.

\section{Design and Data Analysis}

This study used a multiple baseline design (Barlow, Nock, \& Hersen, 2008) across three multiplication fact sets for Dustin and three sets of division facts for Justin. Four sessions of baseline were taken with Set 1, 11 sessions of baseline with Set 2, and 19 sessions of baseline for Set 3 with Justin. A total of 22 sessions were taken for the duration of the study. For Dustin four sessions of baseline were taken with Set 1, seven session of baseline with Set 2, and 16 sessions of baseline with Set 3. A total of 19 sessions were taken over the duration of data collection.

Pretesting. Justin took a written pretest with 90 division facts on it. Justin and Dustin were given 5 minutes to complete the pretest. The researchers corrected it and picked the division facts that Justin had the most errors. Three sets of division facts (Set $1=7$, Set 26 , and Set 3 $=8$ problems) were chosen from his pretest. These were then placed on 3 by 5 inch flashcards and used for the duration the study. Dustin was given a written pretest with 100 multiplication facts. The selected multiplication facts were separated into sets of seven problems. These sets were placed on index cards.

Baseline. Three sets of problems were established for each participant based on their performance on their pretest. Baseline data were taken using all of the flashcards for Sets 1 through 3. Next the researchers slowly and silently counted to two when each card was presented to each participant. If the participants were able to give a correct answer within $2 \mathrm{~s}$, the researcher marked the card correct by marking a plus sign $(+)$ in the corresponding box on the data sheet. If the flashcard was skipped, the participants responded incorrectly, or required great than $2 \mathrm{~s}$ to respond, it was placed on the data sheet as incorrect using a minus sign (-). Baseline data were gathered for 4 to 19 sessions.

DI flashcard system with back three for errors. For each session during the intervention, all three sets of flashcards were presented. Participants were instructed to verbally state the en- 
tire problem and answer. If either participant gave the wrong answer or verbally delayed for greater than $2 \mathrm{~s}$, the card would be reviewed with a model, lead and test procedure (MarchandMartella et al., 2004; Peterson, McLaughlin, Weber, Derby, \& Anderson, 2008) and placed back in the deck three cards from the top. Therefore, the participants were provided additional opportunities to make the correct response only after three other flashcards had been presented. This process was repeated for each set until the participants could correctly state and answer each previously unknown fact for three sessions in a row. Once the participants reached mastery for Set 1, the flashcard system for Set 2 was implemented, until all three sets were taught.

Posttest. The pretest worksheet was readministered following mastery for both boys following mastery of each math set.

\section{Reliability of Measurement and Fidelity of the Independent Variable}

Interobserver agreement was taken by having the second researcher record data simultaneously but independently during a portion of the sessions. The secondary observer took data on the data collection sheets approximately $77.5 \%$ of the time. The number of incorrect and correct responses was compared between the observer's agreement and disagreements were used to determine reliability. If each observer scored the student work in the same manner it was scored as an agreement. Any deviation in scoring was defined as a disagreement. The percent of agreement was calculated by dividing the number of agreements by agreements plus disagreements and multiplying by 100 . Interobserver agreement was $100 \%$. Agreement as to the fidelity of the implementation of the DI flashcard procedure was taken on two occasions. The third author came unannounced to the classroom and monitored the procedure. Agreement regarding the fidelity for the independent variable was $100 \%$. We also gathered these data based on student performance as it was scored on the data collection sheet. The listing of the experimental condition by student and skill was $100 \%$. 


\section{Results}

\section{Baseline}

The results for Justin are shown in Figure 1. During baseline for Set 1, the number of corrects ranged from 0 to $4(M=1.5)$. For baseline in Set 2 , the number of problems correct was low $(M=1.181$ : range 0 to 2$)$. On Set 3 for baseline, Justin's performance improved over time with an increasing trend after the intervention was in completed for Sets 1 and 2 ( $M$ = 2.59; range 0 to 8). During baseline for Set 1 for Dustin, his corrects were low $(M=1.5$; range 0 to 4$)$. For Set 2, his corrects were low $(M=.571$; range 0 to 2$)$. On Set 3 , he showed improvement after flashcards with back three were being employed for Sets 1 and 2. His overall mean for baseline was 3.25 ; range 0 to 7 ).

\section{Flashcards with Back Three}

Justin's results showed immediate improvement for Set $1(M=$ range 3 to 7$)$. For Set 2, his corrects increased to a mean of 5.27 with a range of 3 to 6 (out of a possible 6.0). For Set 3 , Justin had perfect performance ( 8 out of 8 possible on sessions 20 to 22 ). For Set 1 , Dustin's corrects were perfect from the 5 through the $19^{\text {th }}$ session $(M=7)$. For Set 2 , increases were also found ( $M=5.75$; range 2 to 7$)$. For the last seven sessions, Dustin had perfect performance (7 out of 7). For Set 3, Dustin had perfect performance $(M=7.0)$ on sessions 17 through 19.

\section{Pre- and Posttesting}

At the end of data collection, the first two authors gave the exact same pretest as a posttest at the end of the final session. Justin showed a large increase in his corrects going from 74 out of 90 correct on the pretest to 82 out of 90 correct on the posttest. For Dustin, he did show an increase from 44 out of 100 possible correct on the pretest to 61 out of 100 on the posttest. 
DI Flashcards Three Back
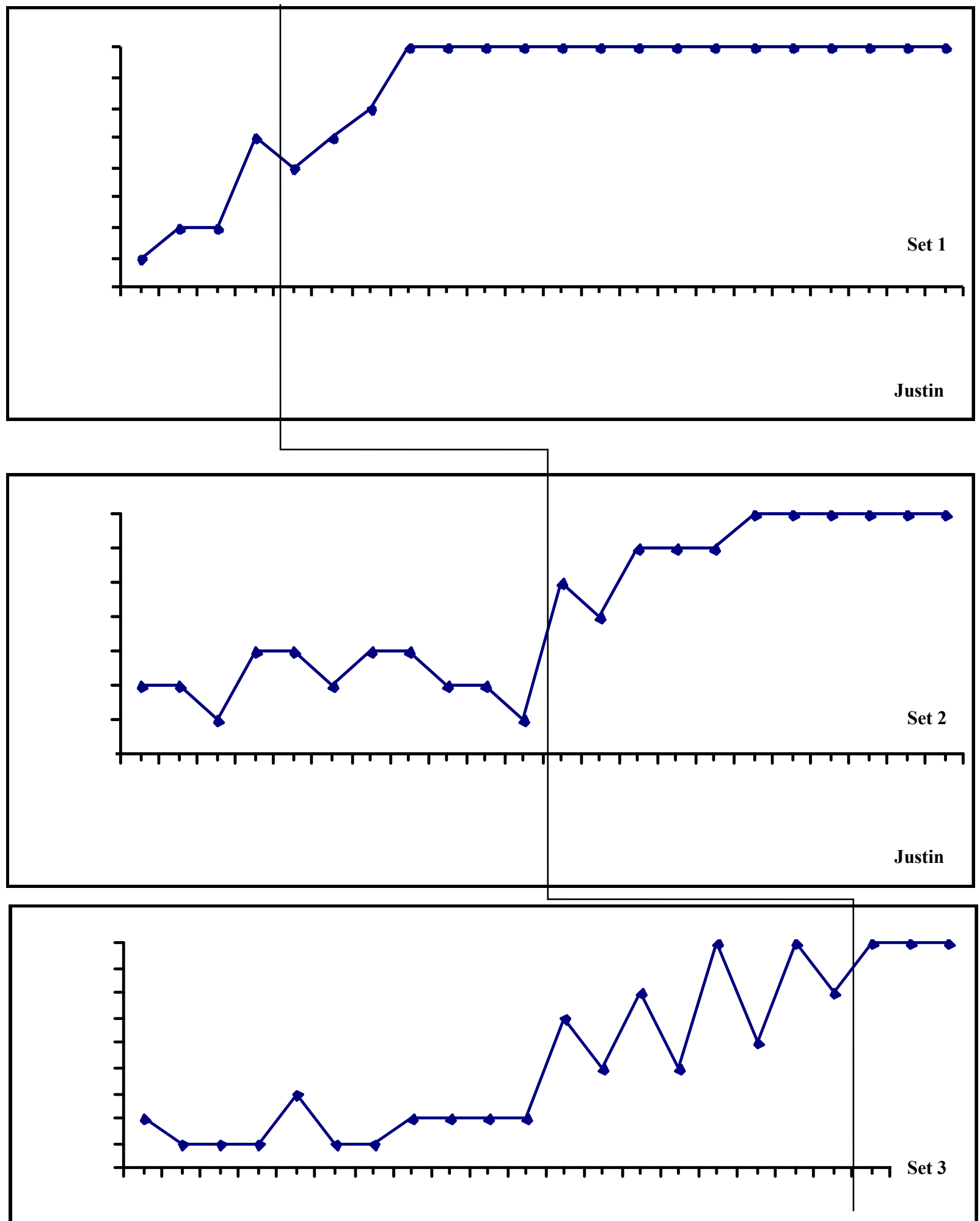

Justin

Figure 1. The number of correct math facts in division for Justin across Sets 1-3 for baseline and DI flashcards three back with Justin. 


\section{Baseline DI Flashcards Three Back}

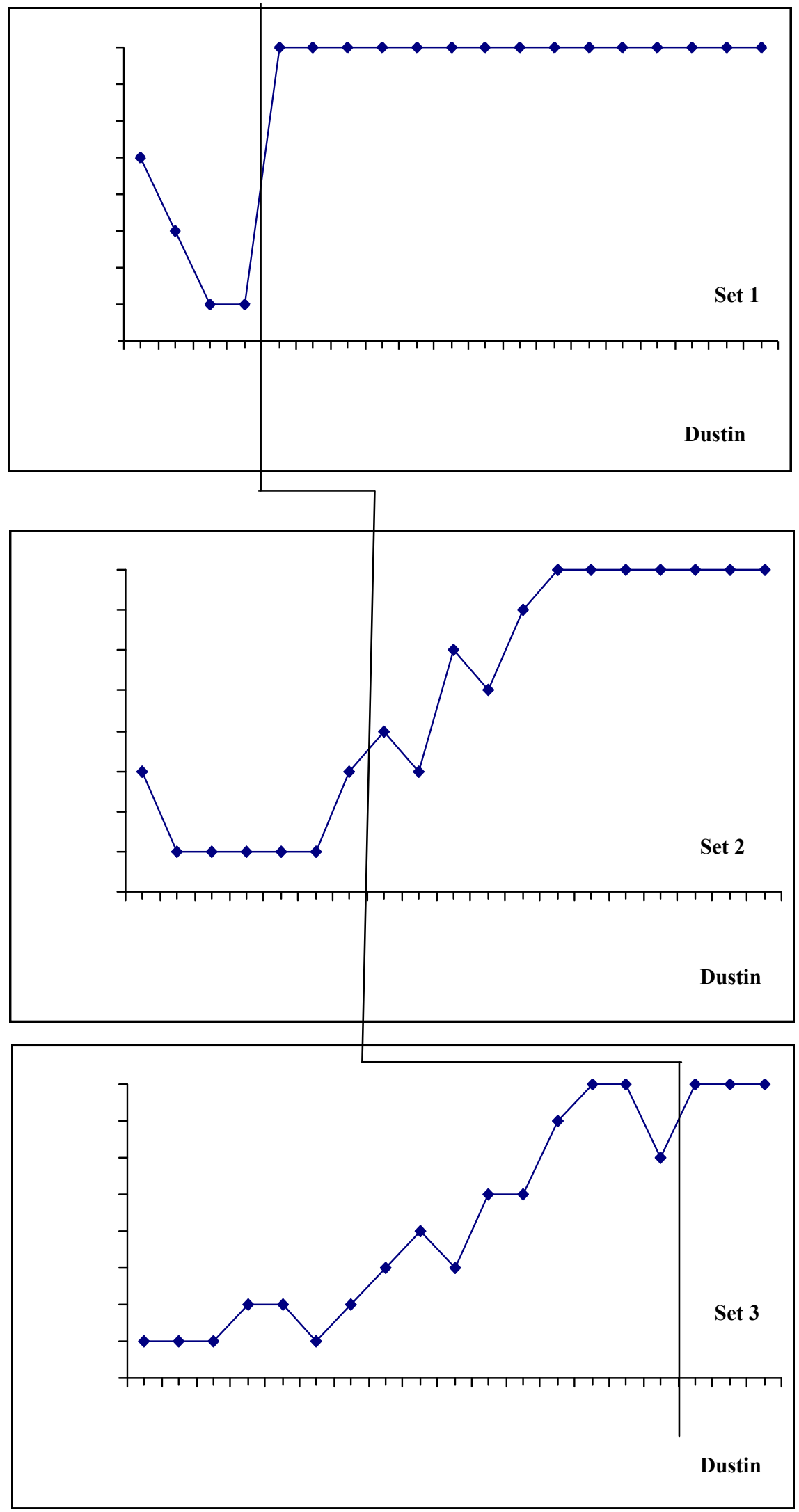

Figure 2. The number of correct math facts in multiplication across Sets 1 - 3 in baseline and for the DI flashcards three back with Dustin 


\section{Discussion}

The present findings provide additional support for the efficacy of the DI flashcard procedure. The outcomes provide an additional replication of our previous research (Brasch et al., 2008; Sante Delli et al., 1999; Hayter et al., 2007). In the present investigation, DI flashcards could be successfully employed in a resource room setting. Since almost $50 \%$ of the students in special education are diagnosed as learning disabled (Heward, 2008), it is important that the DI flashcard procedures were shown to be effective with this group of students. In addition, it provides additional evidence for the recent meta analysis by Kroesbergen and Van Luit (2003) which reported that direct instruction was the most effective procedure to teach basis facts. In addition, as Romero, Lósegui Bandera, Ruiz León, \& Lavigne Cerván (2001) reported, specific skills should be systematically taught to students in educational settings. In the present research, specific math skills were taught to students with leanring disabilities.

The results of this study showed that the DI flashcard procedure with a back three for errors flashcard for teaching basic math facts was successful. Also, there appeared to be some generalization to the facts on Set 3 for both participants. When asked, the participants reported they were not practicing on their own out of class. This has been known to occur with some of our other interventions such as copy, cover, and compare or peer tutoring (Becker, McLaughlin, Weber, \& Gower, 2009; Malone \& McLaughlin, 1997). However, both believed that just using the cards and additional practicing helped them to retain their mastery of the math facts. Even though set three facts were only shown once a session for baseline data, it appeared that our participants started to learn these facts. Both participants became more confident in themselves and they really appeared to enjoy the adult verbal praise we provided. Each participant was successful at mastering the multiplication and division facts they originally struggled, showing that the back three for errors DI flashcard method was effective.

There were several limitations in the present research. First, we were only able to assess maintenance for a brief period of time. The data collection time period was short due to the completion of the first author's student teaching experience. We were only able to have 19 sessions for Dustin and 22 sessions for Justin. It would have been beneficial to have been able to assess maintenance of treatment effects for the following school year. Both students moved up to a local middle school and this was not possible. Second, the criterion for chang- 
ing sets needs further investigation. We required our participants to have three sessions with perfect performance before moving to the next set. It may be that fewer sessions are needed. Another interesting finding was the generalization of student outcomes to Set 3 prior to systematic instruction. We went back and examined their work and found that none of these problems were being presented in Sets 1 or 2 such as $5 \times 4=n$ or $4 \times 5=n$ were found. Based on the work of Van Houten and Rodien (1989), requiring the students have additional practice with their errors was required. In their research, error cards were placed on the students' knees and represented to the students. Van Houten and Rodien found that their participants increased their correct rates while their sessions to mastery too less time. We did not find such an outcome in this research.

Additional strengths of the study included its efficiency for teaching math skills. Also, that our flashcard process was not only effective, but easy to implement and monitor. Also, much of the same type of grading that teachers carry out in the classroom is required to track student performance using the DI flashcard procedure. Finally, like many behavioral interventions in the classroom such as token program, daily report cards, peer tutoring, cover, copy, and compare, the use of flashcards was very inexpensive. The only item that could not be found in the school was the special reward each participant earned at the end of the investigation. Overall, the investigation proved to be effective and beneficial to the two participants involved.

\section{References}

Altwerger, B., Arya, P., Jin, L., Jordan, N. L., Laster, B., \& Martens, P. (2004). When research and mandates collide: The challenges and dilemmas of teacher education in the era of NCLB. English Education, 36, 119-133.

Barlow, D. H., Nock, M., Hersen, M. (2008). Single case research designs: Strategies for studying behavior change ( $3^{\text {rd }}$ ed.). New York: Allyn and Bacon.

Becker, A., McLaughlin, T. F., Weber, K. P., \& Gower, J. (2009). The effects of copy, cover, and compare with and without error drill on multiplication fact fluency and accuracy. Electronic Journal of Research in Educational Psychology, 18, 747-760.

Brasch, T. L., Williams, R. L., \& McLaughlin, T. F. (2008). The effects of a direct instruction flashcard system on multiplication fact mastery by two high school students with ADHD and ODD. Child \& Family Behavior Therapy, 30(1), 51-59. 
Hayter, S., Scott, E., McLaughlin, T. F., \& Weber, K.P. (2007). The use of a modified direct instruction flashcard system with two high school students with developmental disabilities. Journal of Developmental and Physical Disabilities, 19, 409-415.

Heron, T. E., Heward, W. L., Cooke, N. L., \& Hill, A. S. (1983). Evaluation of a classwide peer tutoring system: First graders teach each other sight words. Education and Treatment of Children, 6, 137-152.

Heward, W. L. (2008). Exceptional children: An introduction to special education (8 ${ }^{\text {th }}$ ed.). Upper Saddle River, NJ: Merrill/Prentice-Hall

Johnson, K. R., \& Layng, T. V. (1994). The Morning Side model of generative instruction. In R. Gardner III, D. M. Sainato, J. O. Cooper, T. E. Heron, W. L. Heward, J. W. Eshelman, \& T. A. Grassi (Eds.). Behavior analysis in education: Focus on measurably superior instruction (pp. 173-197). Pacific Grove, CA: Brooks/Cole.

Kroesbergen, E. H., \& Van Luit, J. E. H. (2003). Mathematics interventions for children with special needs: A meta-analysis. Remedial \& Special Education, 24, 97-114.

Livingstone, D. W. (1998). The education-jobs gap: Underemployment or economic democracy. Boulder, Co: Westview.

Maheady, L., \& Sainato, D. M. (1985). The effects of peer tutoring upon the social status and social interaction patterns of high and low status elementary school students. Education and Treatment of Children, 8, 51- 65.

Malone, R., \& McLaughlin, T. F. (1997). The effects of reciprocal peer tutoring with a group contingency on quiz performance in vocabulary with seventh and eighth grade students. Behavioral Interventions, 12, 27-40.

Marchand-Martella, N., Slocum, T., \& Martella, R. (Eds). (2004). Introduction to direct instruction. Upper Saddle River, NJ: Pearson Education.

McLaughlin, T. F., Williams, B. F., Williams, R. L., Peck, S. M., Derby, K. M., Bjordahl, J. M., \& Weber, K. M. (1999). Behavioral training for teachers in special education: The Gonzaga University program. Behavioral Interventions, 14, 83-134.

Olenick, D. L., \& Pear, J. J. (1980). Differential reinforcement of correct responses to probes and prompts in picture-name training with retarded children. Journal of Applied Behavior Analysis, 13, 77-89.

No Child Left Behind Act of 2001, Pub. L. No. 107-110, 20 U.S.C.-1425 et seq. 
Peterson, L., McLaughlin, T. F., Weber, K. P., Derby, K. M., \& Anderson, H. (2008). The effects of a model, lead, and test technique paired with visual prompts with a fading procedure to teach "where" to a 13-year-old echolalic boy with autism. Journal of Developmental and Physical Disabilities, 20,31-39.

Rivera-Batiz, F. L. (1992). Quantitative literacy and the likelihood of employment among young adults in the United States. Journal of Human Resources, 27, 313-328.

Romero, J. F., Lósegui Bandera, E., Ruiz León, I., \& Lavigne Cerván, R. (2001). Application of a written composition and reading comprehension program in primary education students. Electronic Journal of Research in Educational Psychology, 1(2), 57-78.

Sante-Delli. A., McLaughlin T. F., \& Weber, K. P. (2001). The use and evaluation of a Direct Instruction flash card strategy on multiplication facts mastery with two students with ADHD. Journal of Precision Teaching and Celeration, 17(2), 68-75.

Silbert, J., Carnine, D. W., \& Stein, M. (1981). Direct instruction mathematics. Columbus, OH: Charles E. Merrill.

Stein, A., Kinder, D., Silbert, J., \& Carnine, D. W. (2006). Designing effective mathematics instruction: A direct instruction approach. Upper Saddle River, NJ: Merrill/Pearson Education, Inc.

Stood, S., \& Jitendra, A. K. (2007). A comparative analysis of number sense instruction in reform-based and traditional mathematics textbooks. Journal of Special Education, 41, 145-157.

United States Congress. (2002). No Child Left Behind Act of 2001. Public Law 107-10. 107th Cong., Pp. 1425-2095.

Van Houten, R., \& Rolider, A. (1989). An analysis of several variables influencing the efficacy of flash card instruction. Journal of Applied Behavior Analysis, 22, 111-120.

Young, C. C., Hecimovic, A., \& Salzberg, C. L. (1983). Tutor-tutee behavior of disadvantaged kindergarten children during peer teaching. Education and Treatment of Children, 6, 123-135. 